\title{
A syndrome of insulin resistance resembling leprechaunism in five sibs of consanguineous parents
}

\author{
L I Al-Gazali, M Khalil, K Devadas
}

\begin{abstract}
Leprechaunism is a rare autosomal recessive disorder associated with extreme insulin resistance with paradoxical hypoglycaemia. It is characterised by prenatal and postnatal growth retardation, reduced subcutaneous tissue, coarse features, acanthosis nigricans, enlarged genitalia, and death in the first year of life. Defects in both the insulin receptor and postreceptor steps of the insulin action pathway have been reported. At the molecular level, several mutations have been described.

The patients reported here are from a Yemeni family with a syndrome of insulin resistance similar to leprechaunism in which the parents are second cousins and five of their eight children are affected. However, the phenotypes seem to be less severe than the classical leprechaunism previously described. All the children are alive (oldest 11 years), there is normal subcutaneous tissue, and a normal growth pattern in some of them. It may be that this is a milder type of leprechaunism with a better prognosis, perhaps caused by a different type of mutation from those previously described. ( $f$ Med Genet 1993;30:470-5)
\end{abstract}

Leprechaunism is a rare autosomal recessive disorder characterised clinically by intrauterine growth retardation, diminished fat and muscle tissue, characteristic facies, acanthosis nigricans, enlarged genitalia, and early death. ${ }^{1}$ Biochemical abnormalities include hyperinsulinaemia, insulin resistance, and impaired glucose homeostasis. ${ }^{23}$

This syndrome was originally described by Donohue ${ }^{4}$ in 1948 who reported a female infant looking like an elf with multiple endocrine abnormalities. This was presented as a case of 'dysendocrinism'. In 1954 a similar child was born to the same family and Donohue and Uchida $^{1}$ proposed the term 'leprechaunism' for this condition.

In the consanguineous Yemini family reported here five children are affected by a syndrome of insulin resistance resembling leprechaunism, but the disorder seems to be less severe than the classical previously described type.

Family report

The family consists of second cousin parents (mother 28 years and father 33 years) of
Yemini origin with eight children, five of whom have the disorder, four males and one female (fig 1). Both parents appear normal.

CASE 1

The proband (IV.3), a boy, was born in 1983 after a normal pregnancy and delivery. His birth weight was $2500 \mathrm{~g}$. He had convulsions immediately after birth and was found to have hypoglycaemia with a fasting blood sugar of $0.8 \mathrm{mmol} .1^{-1}$ and a serum insulin level of $247 \mu \mathrm{U} \cdot \mathrm{ml}^{-1}$. He was treated with frequent feeding, prednisolone, and later diazoxide but with no response. At the age of 7 months he underwent subtotal pancreatectomy. Histopathology disclosed islet cell hyperplasia with no signs of nesidioblastosis. His therapy remained as before. Nevertheless at 9 months of age further pancreatic excision was done and only a small crescent of pancreatic tissue was left. He continued, however, to have symptomatic hypoglycaemia and his insulin level remained high at $1000 \mu \mathrm{U} \cdot \mathrm{ml}^{-1}$. At 4 years of age he spent three days on a ventilator because of coma and seizures. At the age of 5 years he developed a full blown picture of diabetes mellitus with polyuria and polydipsia. His blood sugar was $27 \mathrm{mmol} . \mathrm{1}^{-1}$ with a simultaneous insulin level of $1000 \mu \mathrm{U} \cdot \mathrm{ml}^{-1}$. He is 7 years old now and on no medication. He still has frequent symptomatic hypoglycaemia and is moderately mentally retarded. His weight is $17 \mathrm{~kg}$, height $112 \mathrm{~cm}$, and head circumference $48 \mathrm{~cm}$, all below the 5 th centile. $\mathrm{He}$ has the following dysmorphic features (fig 2A, table 1): widely spaced eyes, depressed nasal bridge with flared alae nasi, thick lips, large ears, gum hypertrophy, prominent nipples, and distended abdomen with large genitalia (fig 2B).

$\mathrm{He}$ has acanthosis nigricans at the back of the neck, in both armpits, and in the abdomen and groin (fig 2C). There is generalised hypertrichosis and scattered white scalp hair (fig 2D). The toe nails are short and convex. He has large hands and feet with brachydactyly.

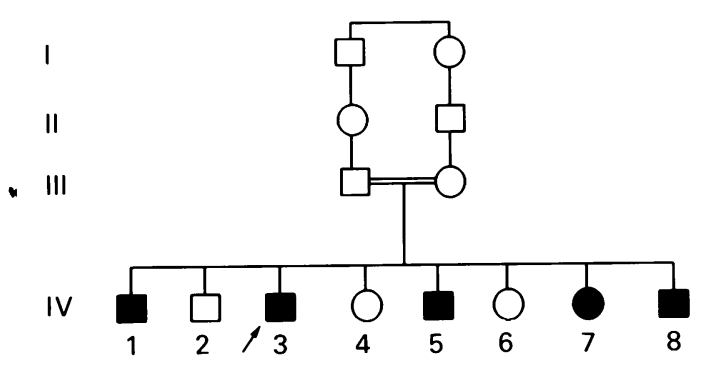

Figure 1 Family pedigree. 

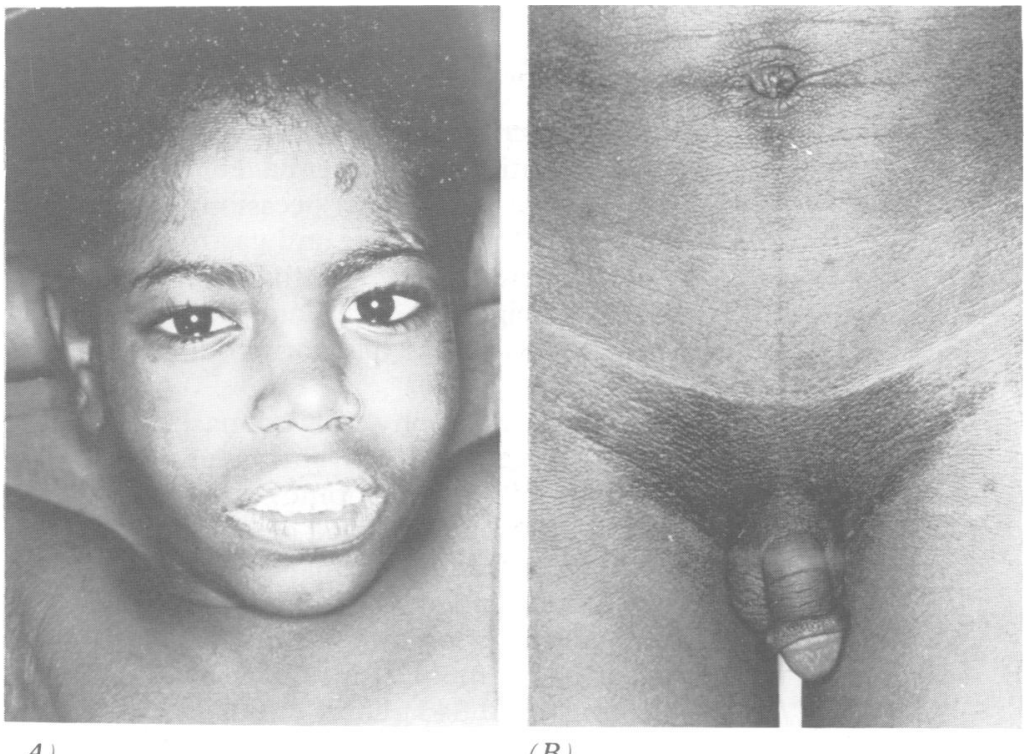

A)

(B)
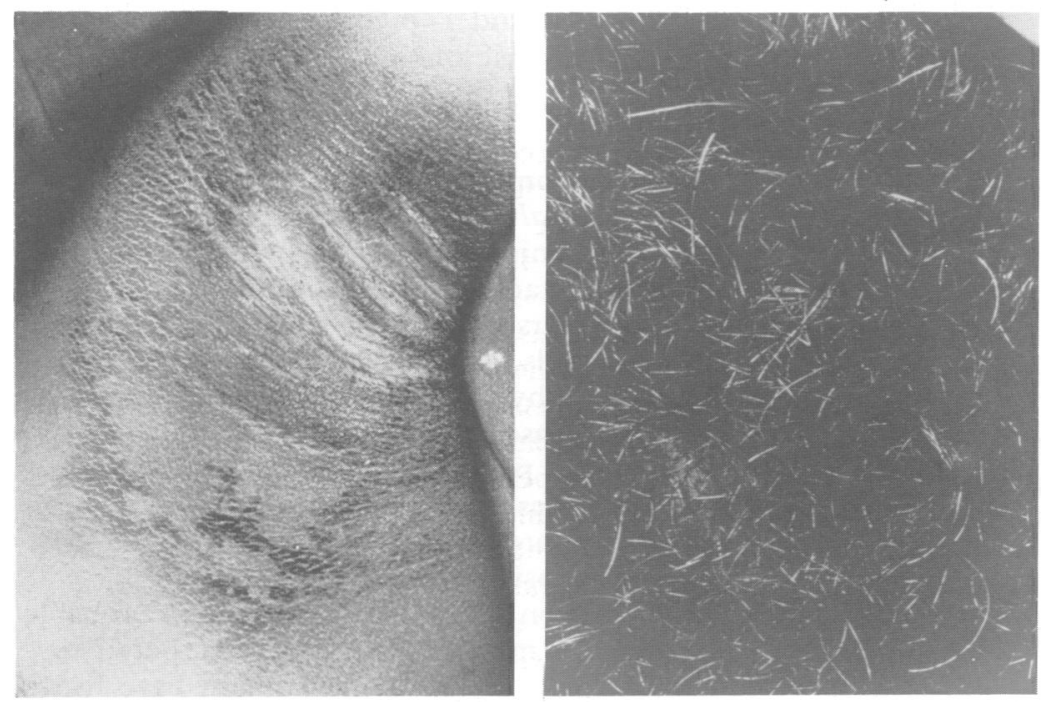

$(C$

Figure 2 The characteristic phenotype in IV.3 showing (A) typical facies with hypertelorism, flared alae nasi, thick lips, (B) enlarged genitalia, (C) acanthosis nigricans, and (D) scattered white scalp hair.

There is no reduction in subcutaneous fat and muscle.

Auscultation indicated a loud systolic murmur (grade V) at the left sternal edge, and echocardiography showed thickened myocardial muscles of the left and right ventricles. Renal ultrasound showed bilaterally enlarged kidneys (right $4.3 \mathrm{~cm}$, left $4.9 \mathrm{~cm}$ ). He has a bone age of 5 years at the chronological age of 7 years. EEG and CT scan were normal.

Relevant laboratory investigation include fasting blood sugar of $0.8 \mathrm{mmol} .1^{-1}$ and an insulin level of $1000 \mu \mathrm{U} \cdot \mathrm{ml}^{-1}$.

\section{CASE 2}

A girl (IV·7) was born at term by normal delivery in 1988 after an uneventful pregnancy. The birth weight was $2500 \mathrm{~g}$. She developed convulsions at the age of 40 days and was found to have a blood sugar level of $0.8 \mathrm{mmol} . \mathrm{1}^{-1}$. She was discharged from hospital at the parents' request and did not attend for follow up. At the age of 4 months she was readmitted to hospital because of a prolonged hypoglycaemic attack. Subsequently, frequent feeds and diazoxide controlled these attacks.

At present she is 4 years old and the parents have discontinued all her medication for he last year giving her only frequent food.

Her weight is $12 \mathrm{~kg}$, height $87 \mathrm{~cm}$, and hcad circumference $49 \mathrm{~cm}$. She has the same phenotype as her brother (fig 3A,B, table 1), except she has normal developmental milestones. Abdominal ultrasound showed bilaterally enlarged ovaries, around $3 \mathrm{~cm}$ in size, with no cyst formation.

Echocardiography showed thickened myocardial muscles of the left and right ventricles. Kidney ultrasound showed bilaterally enlarged kidneys (right $9 \cdot 1 \mathrm{~cm}$, left $10.4 \mathrm{~cm}$ ). CT scan of the brain and EEG were normal. Bone age corresponded to chronological age. Chromosome analysis showed an apparently normal female karyotype $(46, \mathrm{XX})$. Her lowest blood sugar recorded was $0.7 \mathrm{mmol} .1^{-1}$ with a fasting insulin level of $131 \mu \mathrm{U} \cdot \mathrm{ml}^{-1}$. The highest recorded insulin level was $1050 \mu \mathrm{U} \cdot \mathrm{ml}^{-1}$.

CASE 3

A boy (IV-1) was born in 1980 by normal delivery after a normal term pregnancy. The birth weight was $2800 \mathrm{~g}$. Soon after birth he started to have hypoglycaemic attacks during which he went limp and blue and both eyes rolled up. No specific treatment was given and the mother was able to control these attacks with frequent feeding. $\mathrm{He}$ is 11 years old now and still gets attacks of abnormal behaviour if not fed frequently. $\mathrm{He}$ is, however, attending school and is doing well at the appropriate age grading.

Examination at the age of 11 years showed a weight of $30 \mathrm{~kg}$, height of $137 \mathrm{~cm}$ (both on the 25 th centile), and head circumference of $53 \mathrm{~cm}$. He has a similar phenotype to his other sibs (fig 4A-C, table 1).

Echocardiography showed moderate thickening of the left and right ventricular muscles. Renal ultrasound showed slightly enlarged kidneys (right $10 \cdot 2 \mathrm{~cm}$, left $10 \cdot 2 \mathrm{~cm}$ ).

Relevant laboratory investigations were: fasting blood sugar of $2 \cdot 2 \mathrm{mmol} .1^{-1}$. The lowest and highest levels of insulin were $74 \mu \mathrm{U} \cdot \mathrm{ml}^{-1}$ and $1690 \mu \mathrm{U} \cdot \mathrm{ml}^{-1}$, respectively.

\section{CASE 4}

A boy (IV.5) was born in 1986 after an uneventful pregnancy by normal vaginal delivery. His birth weight was $2500 \mathrm{~g}$. He appeared normal until the age of 2 years when he started to have attacks of sweating and loss of vision after prolonged fasting. The parents have managed these attacks by frequent feeding. $\mathrm{He}$ has normal developmental milestones.

Examination at the age of 5 years showed a weight of $19 \mathrm{~kg}$ and a height of $108 \mathrm{~cm}$, on the 25 th and 50 th centiles respectively. His head circumference is $49 \mathrm{~cm}$. He has a very similar phenotype to his other sibs (fig 5, table 1).

Echocardiography showed thickened myo- 
Table 1 Clinical features of the five sibs compared to the features of leprechaunism.

\begin{tabular}{|c|c|c|c|c|c|c|}
\hline & IV $\cdot 1$ & IV $\cdot 3$ & IV.5 & IV.7 & IV 8 & $\begin{array}{c}\text { Leprechaunism }^{5-7} \\
\text { (52 cases })\end{array}$ \\
\hline Sex & $M$ & $\mathbf{M}$ & $M$ & $\mathrm{~F}$ & $M$ & $\begin{array}{l}16 \mathrm{M}, 31 \mathrm{~F} \\
5 \text { unknown }\end{array}$ \\
\hline $\begin{array}{l}\text { Birth weight (g) } \\
\text { Weight (centile) }\end{array}$ & $\begin{array}{l}2800 \\
25 \text { th }\end{array}$ & $\begin{array}{l}2500 \\
<5 \text { th } \\
<5 \text { th }\end{array}$ & $\begin{array}{l}2500 \\
25 \text { th } \\
50 \text { th }\end{array}$ & $\begin{array}{l}2500 \\
<5 \text { th } \\
<5 \text { th }\end{array}$ & $\begin{array}{l}2800 \\
<5 \text { th } \\
<5 \text { th }\end{array}$ & $\begin{array}{c}1590-4250 \mathrm{~g} \\
<3 \text { rd centile } 21 / 51\end{array}$ \\
\hline $\begin{array}{l}\text { Height (centile) } \\
\text { Mentally retarded }\end{array}$ & 25th & $\begin{array}{c}<5 \text { th } \\
+\end{array}$ & 50th & $<5$ th & $<5$ th & 20 \\
\hline Survival & $\begin{array}{l}\text { Alive } \\
11 \mathrm{y}\end{array}$ & $\begin{array}{l}\text { Alive } \\
7 \mathrm{y}\end{array}$ & $\begin{array}{c}\text { Alive } \\
5 \mathrm{y}\end{array}$ & $\begin{array}{c}\text { Alive } \\
4 \mathrm{y}\end{array}$ & $\begin{array}{l}\text { Alive } \\
1.7 \mathrm{y}\end{array}$ & $\begin{array}{l}\text { Early death } 32, \\
\text { alive } 19\end{array}$ \\
\hline \multicolumn{7}{|l|}{ Craniofacial } \\
\hline Hypertelorism & + & + & + & + & + & 25 \\
\hline Depressed nasal bridge & + & + & + & + & + & 34 \\
\hline Flared nostrils & + & + & + & + & + & 34 \\
\hline Long/low ears & + & + & - & - & - & 41 \\
\hline Thick lips & + & + & + & + & + & 30 \\
\hline Gum hypertrophy & + & + & - & + & + & 11 \\
\hline \multicolumn{7}{|l|}{ Trunk and extremities } \\
\hline $\begin{array}{l}\text { Abdominal distension } \\
\text { A }\end{array}$ & $\begin{array}{l}+ \\
+\end{array}$ & + & + & + & $\begin{array}{l}+ \\
+\end{array}$ & $\begin{array}{l}23 \\
21\end{array}$ \\
\hline Enlarged genitalia & + & + & + & + & + & 36 \\
\hline Large hands and feet & + & + & + & + & + & ? \\
\hline Brachydactyly & + & + & + & + & + & 2 \\
\hline \multicolumn{7}{|l|}{$\begin{array}{l}\text { Cutaneous manifestations } \\
\text { Hypertrichosis (body and }\end{array}$} \\
\hline Acanthosis nigricans & + & + & + & + & + & $7 / 25$ \\
\hline Wrinkled, loose skin & - & - & - & - & - & 30 \\
\hline$\downarrow$ subcutaneous fat & - & - & - & - & - & 47 \\
\hline Hyperkeratosis & + & + & + & + & + & $8 / 25$ \\
\hline Rugation of orifice & + & + & + & + & + & 18 \\
\hline Dysplastic convex nails & + & - & + & + & + & 4 \\
\hline $\begin{array}{l}\text { Change in hair } \\
\text { colour }\end{array}$ & - & $\stackrel{+}{+}$ & - & - & - & $\stackrel{2}{2}$ Reddish \\
\hline \multicolumn{7}{|l|}{ Other manifestations } \\
\hline Heart murmur & + & + & + & + & + & 15 \\
\hline Myocardial hypertrophy & + & + & + & + & + & 3 \\
\hline Ovarian enlargement & & & & + & & 9 \\
\hline Respiratory problems & + & + & + & + & + & 10 \\
\hline Poor feeding & + & + & - & + & + & 15 \\
\hline Rectal prolapse & - & - & - & - & - & 4 \\
\hline Kidney enlargement & + & + & + & + & + & 5 \\
\hline
\end{tabular}

cardial muscles of the left and right ventricles. Renal ultrasound showed bilaterally enlarged kidneys (right $4.9 \mathrm{~cm}$, left $10 \mathrm{~cm}$ ). Laboratory investigations showed a blood sugar of $1.3 \mathrm{mmol} \cdot \mathrm{1}^{-1}$ and insulin level of $656 \mu \mathrm{U} \cdot \mathrm{ml}^{-1}$.

CASE 5

A boy (IV.8) was born in 1990 by normal vaginal delivery after an uneventful term pregnancy. His birth weight was $2600 \mathrm{~g}$. He was
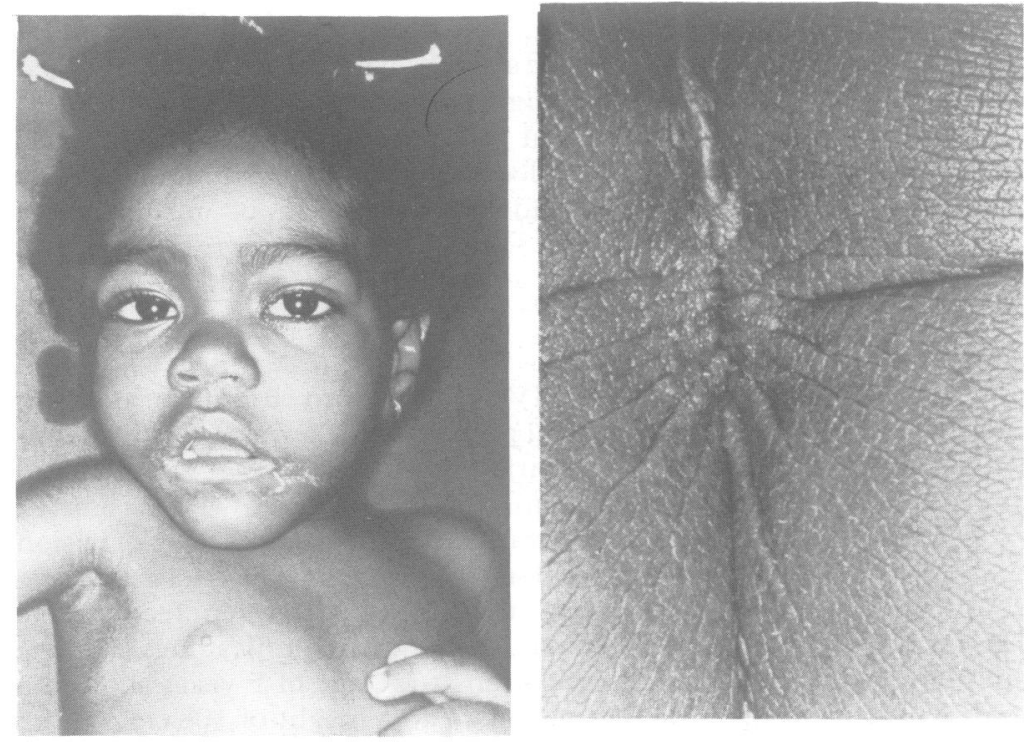

(A)

(B)

Figure 3 (A) Facial appearance of case 2 (note the prominent nipple) and $(B)$ rugosity of the anal region. found to have the same phenotype as his other sibs (fig 6, table 1), and because the mother was aware of the problem she started feeding him frequently. As a result he did not develop symptomatic hypoglycaemia. He was admitted to hospital on a few occasions because of asthmatic bronchiolitis and gastroenteritis.

He is now 1 year 7 months old with a weight of $8 \mathrm{~kg}$, height of $73 \mathrm{~cm}$, and head circumference of $48 \mathrm{~cm}$. He has normal developmental milestones.

Echocardiography showed markedly hypertrophied right and left ventricular muscle suggestive of hypertrophic cardiomyopathy. Renal ultrasound showed an enlarged left kidney $(8.1 \mathrm{~cm})$ and a normal right kidney. Bone age corresponded to chronological age.

Relevant laboratory results included blood sugar of $2 \mathrm{mmol.1^{-1 }}$, insulin level $64 \mu \mathrm{U} \cdot \mathrm{ml}^{-1}$ (fasting), and $845 \mu \mathrm{U} \cdot \mathrm{ml}^{-1}$ (postprandial).

In all five sibs serum levels of glucagon, cortisol, somatomedin C, FSH, LH, T3, $\mathrm{T} 4, \mathrm{TSH}$, and 17-hydroxyprogesterone were within normal limits.

\section{Discussion}

Elsas et $a l^{8}$ summarised the phenotype of leprechaunism as follows: severe intrauterine growth retardation, small elfin face with protuberant ears, distended abdomen, relatively large hands, feet, and genitalia, and abnormal skin with hypertrichosis, acanthosis nigricans, and decreased subcutaneous fat. The majority of the 52 previously reported patients share most of these typical features of leprechaunism but there are others who do not ${ }^{9-13}$ and in these the diagnosis has been questioned.

Patterson and Watkin ${ }^{9}$ described a probable case in a male patient, but later Patterson ${ }^{13}$ suggested that this patient might have had a different disorder, since there were clinical signs of 'Cushing's disease' with enlarged adrenals and severe changes in the bones at necropsy. David and Goodman ${ }^{14}$ reported similar observations under the name 'Patterson syndrome'. Dallaire et $a l^{12}$ described three infants with generalised elastic fibre deficiency and leprechaunoid features. The majority $(61 \cdot 1 \%)$ of the cases in whom the diagnosis was unequivocal died in the first year of life, $90 \%$ of cases had loss of subcutaneous fat, $41 \%$ had poor weight gain after birth, $42 \%$ of cases had intrauterine growth retardation, and $38 \%$ of cases had mental retardation (table 1 ).

The five children in this report have many of the features of leprechaunism (table 1) but seem to be less severely affected than the previously reported cases. They are all alive and are mentally normal apart from one patient (IV.3) whose mental deficiency could be attributed to prolonged hypoglycaemic attacks. None has any reduction in subcutaneous fat. The hypoglycaemia seen in all these children is easily controlled by frequent feeding. Three have mild growth retardation (IV 3 , IV.7, IV.8) and two have normal growth patterns (IV·1, IV · 5), but none suffered intrauterine growth retardation.

However, all five children have kidney 


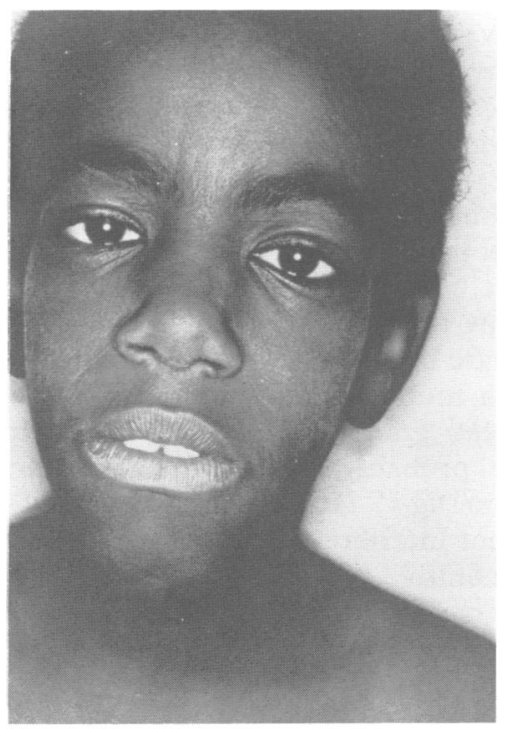

( $A$ )

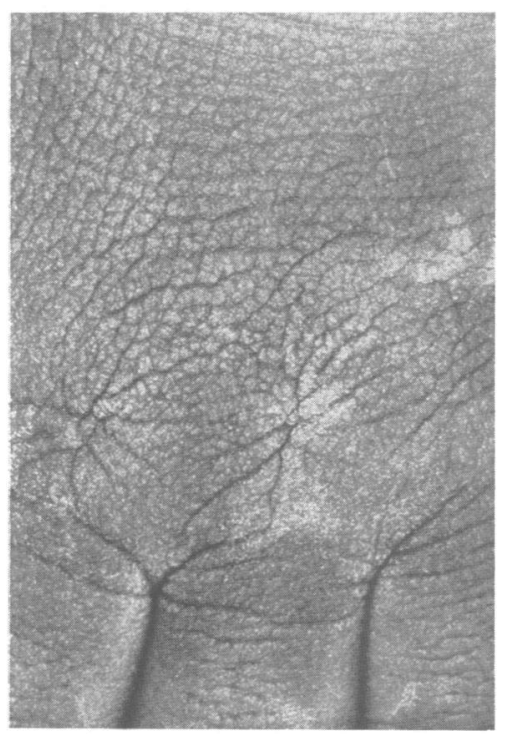

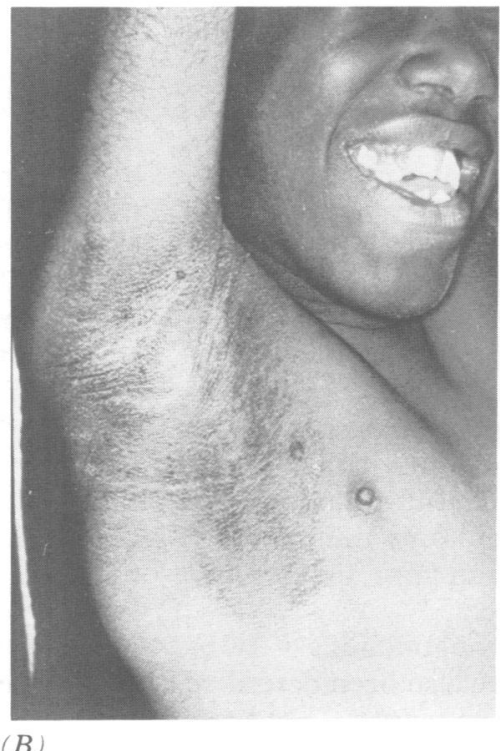

(B)

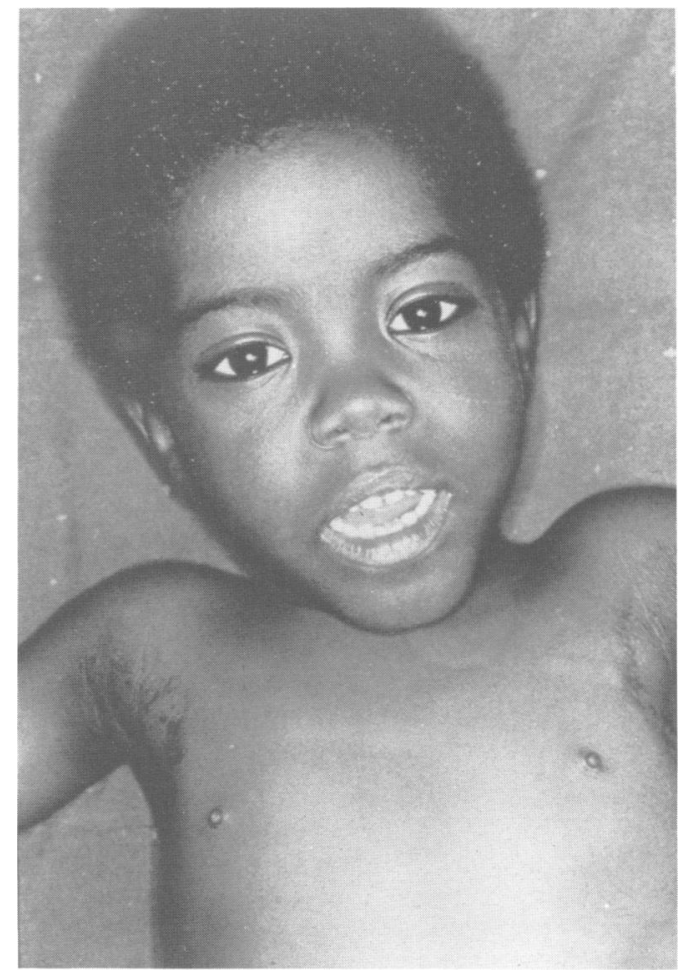

Figure 5 Characteristic facial appearance with acanthosis nigricans and prominent nipple in IV.5.

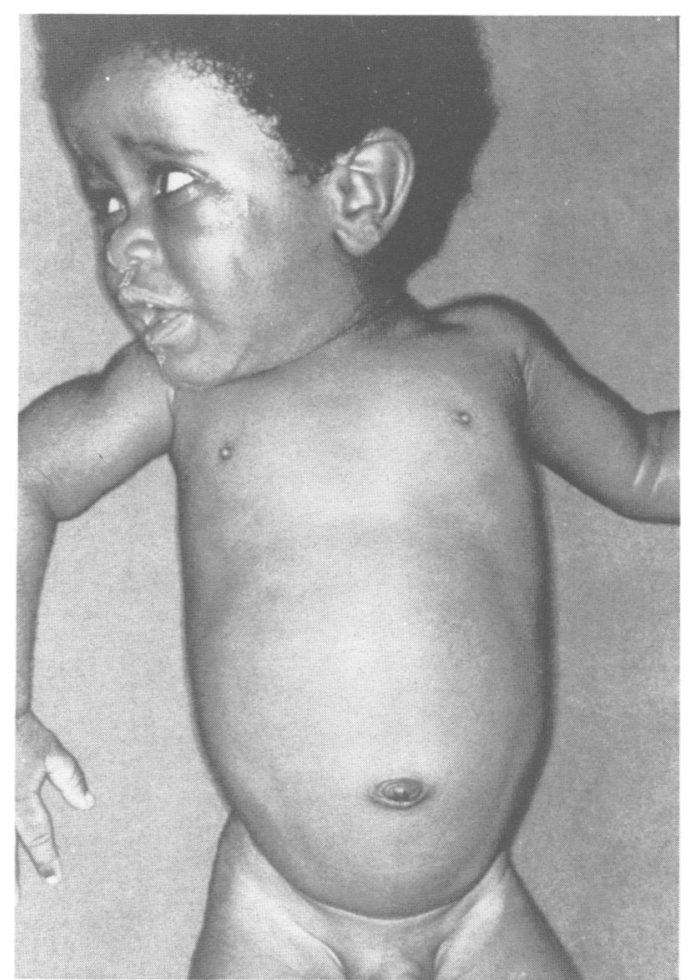

Figure 6 Abdominal distension in IV.8.

Fasting hypoglycaemia and multiple abnormal features are specific to leprechaunism. ${ }^{16}$ All five sibs in this report showed these features (table 1), but the absence of severe growth retardation, long survival, and normal subcutaneous tissue make it difficult to establish a definite diagnosis of classical leprechaunism in this family. However, there are published reports of patients with leprechaunism who had hypertriglyceridaemia. ${ }^{16}$ Rabson-Mendhall's syndrome is associated with abnormalities of the teeth and nails and reportedly pineal hyperplasia. ${ }^{16}$

enlargement on ultrasound (table 1). This finding has been reported in only five patients found at necropsy, it may be that kidney enlargement had not been suspected in the other patients reported. Histological examination in calcification with tubular dilatation or both. ${ }^{5}$ Ellis et al,,$^{15}$ however, reported a 13 year old leprechaun child with hyperglycaemia and hyperinsulinaemia who had hypertension, findings on renal biopsy were similar to those een in diabetic nephropathy.

ance include type A insulin resistance, lipoatrophic diabetes mellitus, and Rabsondromes share some features in common (for example, acanthosis nigricans and hyperanon the presence or absence of specific clinical features. For example, in lipoatrophic diabetes 
normal birth weight and long survival, yet other clinical features and molecular studies confirmed the diagnosis of leprechaunism..$^{15} 17$

At the molecular level, the main defect in leprechaunism is a mutation in the insulin receptor gene. Many different mutations in this gene have been described (table 2), but all result in either a decrease in the number of insulin receptors of the target cells ${ }^{18}$ or in a defect in the insulin receptor function itself. ${ }^{19} 20$

All these patients studied with leprechaunism have had two mutant alleles of the insulin receptor gene. However, some patients were heterozygous for two different mutations and some homozygous for the same mutation, ${ }^{21-23}$ but there has been no attempt to correlate phenotype with genotype.

In addition defects in the functions of IGF1 and EGF receptors have also been described in fibroblasts from some patients, ${ }^{24} 25$ but there is no description of mutations in the genes encoding IGF-1 and EGF receptors. ${ }^{20}$ Kadowaki et $a l^{22}$ suggested that the insulin receptor gene may regulate the function of receptors for IGF-1 and EGF so that mutations in the insulin receptor gene might indirectly impair the function of receptors for other growth factors, but why this should be the case in some patients and not others is not clear. There is evidence to suggest that at high concentrations insulin acts through the IGF-1 receptor as a mitogen stimulating thymidine uptake, DNA synthesis, and cell replication. The selective action of insulin on some tissues is related to the density or affinity of IGF-1 receptors. ${ }^{6}$

The ovary, heart, kidney, and other vascular endothelium have IGF-1 receptors ${ }^{26-28}$ while human fat cells do not. ${ }^{29}$ This could explain the ovarian enlargement, myocardial hypertrophy, ${ }^{6}$ and the kidney enlargement reported in some patients with leprechaunism. In addition, Funakoshi et $a l^{30}$ reported a case with severe intrauterine growth retardation and abnormalities of IGF-1/SMC receptor functions. They suggested that the severe intrauterine growth retardation was the result of abnormality or immaturity of the IGF-1 receptors.

Table 2 Mutations described in leprechaun patients.

\begin{tabular}{|c|c|c|}
\hline & Mutation $^{21-23}$ & Effect \\
\hline \multirow[t]{2}{*}{ Lep/ARK-1 } & $\begin{array}{l}\text { Allele } 1 \\
\text { Glu }^{672}\end{array}$ & $\begin{array}{l}\text { Truncated receptor, } \\
\text { rapidly degraded }\end{array}$ \\
\hline & $\begin{array}{l}\text { Allele } 2 \\
\text { Glu }^{460}\end{array}$ & $\begin{array}{l}\text { Insulin receptors less } \\
\text { sensitive to changes in pH }\end{array}$ \\
\hline \multirow[t]{2}{*}{ Lep/Minn1 } & $\begin{array}{l}\text { Allele } 1 \\
\text { Nonsense } \\
\text { mutation } \\
\text { codon } 897\end{array}$ & $\begin{array}{l}\downarrow \text { MRNA transcribed } \\
\text { from that allele }\end{array}$ \\
\hline & $\begin{array}{l}\text { Allele } 2 \\
\text { Cis dominant } \\
\text { mutation } \\
\text { (unidentified) }\end{array}$ & $\downarrow$ MRNA \\
\hline Lep/Gelern & $\operatorname{Prol}^{233} / \operatorname{Prol}^{233}$ & $\begin{array}{l}\downarrow \text { insulin binding to surface } \\
\text { of cultured fibroblast }\end{array}$ \\
\hline Lep/Winnipeg & $\operatorname{Arg}^{209} / \mathrm{Arg}^{209}$ & $\begin{array}{l}\text { Disrupts the normal folding } \\
\text { of receptor leading to } \\
\text { defective post-translational } \\
\text { process and impaired } \\
\text { intracellular transport }\end{array}$ \\
\hline
\end{tabular}

All the five children in this report have myocardial hypertrophy, kidney enlargement, and ovarian enlargement in the female, but no intrauterine growth retardation. This would indicate that IGF-1 receptors are normal in this family, but does not explain the presence of subcutaneous tissue and the milder course of the disease.

The parents in this family are second cousins, so they are both likely to be heterozygous carriers for a mutant allele inherited from a common great grandfather. Their affected children are probably homozygous for the same mutation (fig 1). However, such homozygosity may not interfere with $\mathrm{IGF}-1$ receptor function. Definitive answers should be provided by the molecular characterisation of the mutation in this family and such studies are under way.

The author acknowledges with thanks $\mathrm{Dr}$ Simeon Taylor for conducting the molecular studies on this family.

1 Donohue WL, Uchida I. Leprechaunism. $f$ Pediatr 1954;45:505-19.

2 Rosenberg A, Haworth J, Degroot W, Trerenen C, Rechler $M$. A case of leprechaunism with severe hyperinsulinemia. Am $₹$ Dis Child 1980;134:170-5.

3 Kobayashi M, Olefsky JM, Elders J, et al. Insulin resistance due to a defect distal to the insulin receptor. Demonstrations in a patient with leprechaunism. Proc Natl Acad Sci tions in a patient with lepr
$U S A$ 1978;75:3469-73.

4 Donohue WL. Clinicopathologic conference at the Hospital for Sick Children on 'Dysendocrinism'. $\mathcal{f}$ Pediatr 1948;32:739-48

5 Cantani A, Zirndo MG, Tacooni ML. A rare polydysmorphic syndrome. Leprechaunism, review of forty nine cases reported in the literature. Ann Genet (Paris) 1987;30:221-7.

6 Geffner M, Kaplan S, Bersch N, et al. Leprechaunism: in vitro insulin action despite genetic insulin resistance. Pediatr Res 1987;22:286-91.

7 Loan D, Dumitrin L, Belengeanu V, Bistriceanu M, Maximilian C. Leprechaunism: report of two cases and review. Endocrinologie 1988;26:205-9.

8 Elsas LJ, Endo F, Strumlauf F, Elders J, Priest JH. Leprechaunism: an inherited defect in a high affinity Leprechaunism: an inherited defect in a high

9 Patterson JH, Watkin WL. Leprechaunism in a male infant. f Pediatr 1962;60:733-9.

10 Royers DR. Leprechaunism (Donohue syndrome). Am $\mathcal{f}$ Clin Pathol 1966;45:614-19.

11 Dekaban A. Metabolic and chromosomal studies in leprechaunism. Arch Dis Child 1965;40:632-6.

12 Dallaire L, Cantin M, Melancon SB. A syndrome of generalised elastic fibre deficiency with leprechaunoid features. A distinct genetic disease with an autosomal recessive mode of inheritance. Clin Genet 1967;10:1-11.

13 Patterson JH. Presentation of a patient with leprechaunism. In: Bergsma D, ed. Clinical delineation of birth defects. IV. Skeletal dysplasia. Baltimore: William \& Wilkins, 1969:117-21.

14 David R, Goodman RM. The Patterson syndrome, leprechaunism, and pseudo-leprechaunism. $\mathcal{F}$ Med Genet chaunism, and

15 Ellis E, Kemp S, Frindiks JP, Elders MJ. Glomerulopathy in a patient with Donohue syndrome (leprechaunism) in a patient with Donohue sy
Diabetes Care 1991;14:413-14.

16 Taylor SI. Receptor defects in patients with extreme insulin resistance. Diabetes Metab Rev 1985;1:171-202.

17 Frindik JP, Kemp SF, Fiser RH, Schedewi H, Elders J Phenotypic expression in Donohue syndrome: a role for epidermal growth factor. $\mathcal{F}$ Pediatr 1985;107:428-30.

18 Taylor SI, Samuels B, Roth J, et al. Decreased insulin binding in cultured lymphocytes from two patients with extreme insulin resistance. $\mathcal{F}$ Clin Endocrinol Metab 1982;54:919-30.

19 Griag JW, Canner J, Locker EF, Widon B, Elders MJ Mechanism of insulin resistance in cultured fibroblast from a patient with leprechaunism, impaired post binding action of insulin and multiplications stimulating activity. Metabolism 1984;33:1084-96.

20 Taylor SI, Roth J, Blizzard RM, Elders MJ. Qualitative abnormalities in insulin binding in a patient with extreme insulin resistance: decreased sensitivity to alteration in insulin resistance: decreased sec Natl Acad Sci US temperature and

21 Taylor SI, Kadowaki T, Kadowaki H, Accili D, Cama A McKeon C. Mutations in insulin-receptor gene in insulin McKeon C. Mutations in insulin-receptor gene in
resistant patients. Diabetes Care 1990;13:257-9.

22 Kadowaki T, Kadowaki H, Rechler M, et al. Five mutant 
alleles of the insulin receptor gene in patients with genetic forms of insulin resistance. $\not{f}$ Clin Invest 1990;86:254-64. 23 Kadowaki T, Bevin C, Cama A, et al. Two mutant alleles of the insulin receptor gene in a patient with extreme insulin resistance. Science 1988;240:787-90. 24 Van Obberghen-Schilling E, Rechler M, Romanus J, like growth factor I are defective in fibroblasts cultured from a patient with leprechaunism. If Clin Invest 1981;68:1356-65.

25 Massagne J, Freidenberg G, Olefsky J, Czech M. Parallel decrease in the expression of receptors for insulin and insulin like growth factor $I$ in a mutant human fibroblast line. Diabetes 1983;32:541-4.

26 Barbieri RL, Makris A, Ryan KJ. Insulin stimulates andro- gen accumulation in incubations of human ovarian stroma and theca. Obstet Gynecol 1984;64:73S-80S.

27 Breitweser JA, Meyer RA, Spesling MA, Tsang RC, Kaplan $\mathrm{S}$. Cardiac septal hypertrophy in hyperinsulinemic infants. $\mathcal{F}$ Pediatr 1980;90:535-9.

28 Gansler T, Hsu WC, Gramling TS, et al. Growth factor binding and bioactivity in human kidney epithelial cells cultures. In Vitro Cell Dev Biol 1990;26:285-90.

29 Skottner A, Frykhind C, Hansson HA. Experimental research on IGF-1. Acta Paediatr Scand Suppl 1986;325:107-11.

30 Funakoshi T, Morikawa H, Yamasaki A, et al. A case of leprechaunism with disorders of IGF-1/somatomedin C binding proteins and its receptors. Nippon Naibunpi Gakkai Zasshi 1989;65:99-112 (English abstract). 
NOTICE

\section{European School of Medical Genetics: 7th Course}

This course will be held in Sestri Levante, Genoa, 20 to 26 March, 1994. Directors:
Professor V A McKusick (Baltimore), Professor G Romeo (Genoa). Faculty: $S$ Aymé, A Ballabio, M Baraitser, G Barbujani, B Brambati, J-J Cassiman, A Chakravarti, M Devoto, M Gershon, P Goodfellow, D Housman, G Jackson, R Kapur, A Monaco, B Müller, V Pachnis, M Pembrey, B Ponder, G J van Ommen, A Schinzel, G Simoni, $S M$ Tilgham. Topics: Introduction to human molecular genetics, linkage analysis, mouse genetics, population genetics, cancer genetics, physical mapping, positional cloning, candidate genes, clinical dysmorphology, genetic counselling, community genetic services. Registration fee: 350000 Italian lire. Applications: send your CV, a brief description of your research interests, a letter of presentation (if you wish to present a clinical case during an evening session and to apply for a travel fellowship in case there are some available, please state it clearly in your cover letter), and a certificate of your knowledge of English to: M Caterina Cogorno, Laboratory of Molecular Genetics, Istituto G Gaslini, 16148 Genova, Italy. Tel: +39/10/5636370-400, Fax $+39 / 10 / 391254$.

\section{Correction}

In the paper 'A syndrome of insulin resistance resembling leprechaunism in five sibs of consanguineous parents' $(\mathcal{F}$ Med Genet 1993;30:470-5), fig 2B is of IV.1 and fig 3B of IV.5. 